\title{
РОЗБІЙНІ НАПАДИ НА ЖИТЛО ГРОМАДЯН ЯК ОБ'СКТ КРИМІНОЛОГІЧНОГО ДОСЛІДЖЕННЯ
}

\author{
СВІР Павло Володимирович - здобувач Донецького юридичного інституту \\ МВС України \\ DOI:10.32782/NP.2020.1.32 \\ УДК 343.915
}

\begin{abstract}
у статті надана характеристика розбійним нападам на житло громадян 3 позичій кримінологічного підходу. Розкрито елементи кримінологічної характеристики, ознаки та поняття розбійних нападів нажитло громадян. До елементів кримінологічноі характеристики віднесено: об'єкти (житло громадян, розбійний напад як діяльність), суб'єкти та заходи запобігання. Виокремлені характерні ознаки розбійних нападів нажитло громадян, зокрема сукупність спеиіалізованої наукової інбормащї, що включає в себе такі елементи: сочіальну обумовленість; суспільну небезпечність; протиправність; склад злочину; суспільно небезпечні способи, наслідки та інші обставини вчинення злочинів; заходи запобігання. Встановлено, що даний вид розбою поєднує в собі корисливий мотив та насильницькі дї (як бізичного так і психічного характеру) або погрозу їх застосування й посягають на життя $і$ здоров'я людини.

Ключові слова: розбій, власність, житло, кримінологічна характеристика, запобігання.
\end{abstract}

Складною кримінологічною проблемою сьогодення є питання про розбійні напади на житло громадян, характерними рисами яких є підвищена суспільна небезпека та резонанс, який виникає у зв' язку з відкритим, незаконним, насильницьким нападом на власність, поєднаний із посяганням на здоров'я і життя людей, що носить, як правило, груповий організований характер із застосуванням вогнепальної зброї й спрямований на заволодіння матеріальними цінностями.
Кількість вчинених розбійних нападів у загальній структурі злочинності за 2013-2019 роки зросла на $27 \%$ (3 1,6 тис. до 2,2 тис.), а питома вага розбійних нападів на житло громадян 3 25,8\% до 33,9\%, зокрема у 2008 році вчинено 413 таких нападів або 25,8\% від загальної кількості розбоїв в Україні, у 2015 р. - 468 (33,1\%), у 2017 р. - 694 (44,8\%), у 2019 - 502 $(37,9 \%)$. Унаслідок цих кримінальних проявів 32 особи загинуло, 49 - дістали поранення, а матеріальні збитки сягнули близько 100 млн грн. Водночас кількість виявлених у зазначений період організованих груп та злочинних організацій відповідного спрямування зменшилася на $33 \%$, а закінчених провадженням кримінальних правопорушень - на 27\% [1; 2].

Наведені дані переконують, що в умовах перманентної соціальної та економічної кризи, зростання безробіття та падіння матеріального рівня громадян, неможливості задоволення значної частини населення основних потреб легальними способами, продовження конфлікту на Сході країни (нелегальне поширення зброї, боєприпасів та вибухівки, зростання соціально-побутової невлаштованості осіб, яких торкнулися наслідки збройного конфлікту та психологічного напруження), втрати соціального контролю та деяких прорахунків, що були допущені при реформуванні правоохоронної системи, розроблення ефективних заходів запобігання розбійним нападам на житло громадян має стати пріоритетним напрямом державної політики боротьби зі злочинністю, дієвим засобом захисту життя та здоров'я людей й власності. 
Діяння, аби бути злочинним, повинне будь-яким чином об'єктивуватися зовні. Саме в зовнішніх проявах виражаються особливості того чи іншого злочину [3, с. 12].

Однак, так вже склалося в кримінальноправовій літературі, що основний наголос при характеристиці злочину ставиться, як правило, на ознаки складу злочину, а істотні риси того чи іншого суспільно небезпечного діяння як явища реальної дійсності випускаються з уваги, що навряд чи є правильним.

Наведене тим більш актуалізується в аспекті надання характеристики розбою, оскільки склад цього злочину належить до так званих усічених складів, а це призводить до того, що в літературі нерідко такому злочину, як розбій надається і «усічена» характеристика.

Під фізичним насильством, небезпечним для життя чи здоров'я, розуміється легке тілесне ушкодження, що спричинило короткочасний розлад здоров'я або незначну втрату працездатності, середньої тяжкості, тяжке тілесне ушкодження, замах на вбивство, вбивство. Однак слід зазначити, що замах на вбивство та вбивство, що супроводжували розбій, не охоплюються цим складом і вимагають додаткової кваліфікації за відповідним пунктом ч. 2 ст. 115.

До насильства як обов' язкової ознаки розбою належить і насильство, небезпечне для життя в момент заволодіння. Специфіка його полягає в тому, що реальна небезпека для життя існує для потерпілого лише в момент застосування насильства, і фактично воно не призводить до настання смерті. Наприклад, здушення шиї, застосування електроструму, скидання з висоти тощо. Фізичне насильство може бути як відкритим, так і таємним (завдання шкоди потерпілому, який спав) [4, c. 140].

Психічне насильство - це погроза заподіяти таке фізичне насильство або погроза вбивством. Додаткової кваліфікації за ст. 129 тут не потрібно. Насильство при розбої є способом заволодіння майном i, як правило, передує йому. Однак воно може застосовуватися і після заволодіння майном для його утримання. Насильство, небезпечне для життя чи здоров’я, застосоване винним з метою уникнути затримання, вимагає самостійної кваліфіка- ції за сукупністю з крадіжкою чи грабежем» [5, c. 141-142].

Тобто розбій як будь-яке злочинне діяння має своє зовнішнє вираження і певним чином впливає на зовнішній світ. Особливість такого впливу полягає у заподіяні шкоди об'єктам кримінально-правової охорони через конкретні акти суспільно небезпечної поведінки людини, які мають свої властивості, що характеризують цю поведінку як злочин.

Слiд зауважити, що термін «діяння» вживається в КК України, теорії і правозастосовній практиці у двох значеннях: 1) для визначення у ст. 11 КК поняття «злочин», тобто як синонім поняття «злочин»; 2) для характеристики діяння як одного 3 компонентів об'єктивної сторони злочину, яке може виражатися у формі дії або бездіяльності. У цьому підрозділі нашого дослідження поняття діяння розглядатиметься у його другому значенні.

Саме діяння 6 ключовим компонентом будь-якого злочину і обов'язковою ознакою його складу. Воно може бути виражене у вигляді конкретного акту людської поведінки або сукупності таких актів. Поняття діяння визначається як акт поведінки людини, якому притаманні: а) суспільна небезпечність; б) протиправність; в) конкретність; г) свідомість; д) вольове виявлення [5, с. 105].

Суспільна небезпечність діяння, яке визнається злочином, полягає у спричиненні істотної шкоди об'єкту кримінально-правової охорони або створення реальної загрози заподіяння такої шкоди. Суспільна небезпечність органічно притаманна діянню, що й обумовлює необхідність його криміналізації. Дія чи бездіяльність, яка не спричиняє шкоди об'єкту кримінально-правової охорони або не створює загрози заподіяння такої шкоди, не може розглядатися як злочин [5, с. 105]. Тому можна стверджувати, що не існує в реальній дійсності безнаслідкових злочинів, а існують в кримінальному законі склади злочинів, які не містять ознаки наслідків як обов' язкової ознаки даного складу. Зокрема, не містить ознак наслідків усічений склад розбою, однак це не означає, що в реальному житті розбій не спричиняє ніяких суспільно небезпечних наслідків і що у правозастосовній практиці їх не треба встановлювати. Навпаки, слідчо-судова 


\section{Дискусії, обговорення, актуально}

практика ретельно встановлюе всі наслідки розбійних діянь.

Протиправність діяння означає, що злочином визнається тільки те діяння, що передбачене КК України. Тому для наявності об'єктивної сторони злочину необхідно, аби діяння було передбачене конкретною статтею Особливої частини КК. Такий злочин, як розбій передбачено безпосередньо кількома статтями КК - ст. 187, ч. 3 ст. 262, ч. 3 ст. 308 , ч. 3 ст. 312 , ч. 3 ст. 313 , ч. 3 ст. 410 , ч. 2 ст. 433 . Водночас низка діянь, які в реальній дійсності можуть мати характер розбійного посягання, кваліфікуються за іншими спеціальними складами злочинів, які, хоча й не містять поняття «розбій», але генетично пов'язані з ним - ч. 3 ст. 289, ст. 432, 438, 446 КК.

Діяння завжди має конкретний характер. Воно становить собою конкретний акт поведінки людини, який відбувається в певній обстановці, місці й часі і завжди втілюється в конкретній дії чи бездіяльності [5, с. 119]. Конкретність дії при вчиненні розбою обумовлена також конкретним предметом посягання, тобто тією конкретною річчю, якою прагне заволодіти винна особа, бо це прямо визначає кваліфікацію діяння за тією чи іншою статтею, що передбачає відповідальність за розбій або інше діяння, генетично пов'язане 3 ним, але передбачене в якості іншого злочину. Як зазначає Б. С. Волков, без конкретної дії (бездіяльності) немає вольового акту. Вольовий акт знаходить своє відображення у свідомих діях, спрямованих на досягнення певної мети [6, с. 35].

Діяння - це свідомий акт поведінки людини, який завжди є наслідком пізнавальної діяльності, відбиттям у свідомості людини об'єктивного світу. Тому не є діянням у кримінально-правовому значенні такі з них, що не контролюються свідомістю, навіть якщо наслідки таких діянь були 6 суспільно небезпечними.

Діяння повинно бути також вольовим, тобто проявом волі особи, коли вона діє з певних мотивів, переслідує певні цілі [7, с. 126]. Воля - це налаштованість особи на вчинення тих чи інших дій [8, с. 5], а вольовий процес 6 психічним процесом, що починається з усвідомлення потреб і завершується прийняттям рішення, для якого характерним є вибір між різними варіантами соціально значущої поведінки [9, с. 5].

Таким чином, як зазначає Н. М. Ярмиш, воля 6 необхідною умовою активності особи. Вона проявляється в реалізації прийнятого рішення, у здатності керувати собою та своїми психічними функціями. Свідомість і воля - не одне і те ж. Але воля невід'ємна від свідомості, по суті, є їі функцією. Говорячи мовою поезії, воля - це думка, яка переходить у справу [9, с. 13-15]. При цьому воля як налаштованість особи на вчинення тих чи інших дій і реалізацію прийнятого рішення не може бути без певної мети, яку не слід розглядати як виключно суб'єктивний момент певного діяння, оскільки реалізація цієї мети об'єктивується шляхом здійснення винною особою реальних дій.

Тобто кожному розбійному діянню як явищу реальної дійсності притаманні суспільна небезпечність, протиправність, конкретність, свідомість і воля, спрямована на досягнення мети.

Дія - це активна, свідома, суспільно небезпечна, протиправна, конкретна, вольова поведінка суб'єкта злочину. Вона є найбільш поширеною формою суспільно небезпечного діяння. Більшість злочинів, передбачених Особливою частиною КК, можуть бути вчинені тільки шляхом дії. До таких злочинів належить і розбій.

В літературі зазначається, що дія може полягати в одному (одиничному) русі тіла або в їх множинності. Рухи тіла, що становлять дію, повинні мати цілеспрямований характер i отже, поєднуватися метою в єдиний вольовий акт поведінки. Мета як і об'єкт злочину відокремлює дію, обмежує обсяг і межі дії, визначає ії предметний зміст. Інакше кажучи, рухи тіла утворюють дію в кримінально-правовому розумінні, коли вони контролюються свідомістю і спрямовуються волею особи на певний об'єкт [5, с. 121].

Кримінальний закон поняття нападу не містить, у науці кримінального права його зміст уже протягом багатьох років лишається спірним. Водночас, слово «напад» безпосередньо вживається у тексті чинного КК України у восьми статтях (ст. 36, ст. 187, ст. 257, ст. 260, ст. 261, ст. 392, ст. 420, ст. 444 КК України). 
Так, визначаючи поняття нападу стосовно розбою, судова практика, а також більшість кримінологів вважають, що його відкритий характер не завжди є ознакою нападу. Пленум Верховного Суду України в Постанові «Про судову практику у справах про злочини проти приватної власності» від 6 листопада 2009 р. № 10 [10] під нападом за ст. 187 КК України пропонує розуміти умисні дії, спрямовані на негайне вилучення чужого майна шляхом застосування фізичного або психічного насильства, зазначеного в частині першій цієї статті (тобто фізичного насильства, небезпечного для життя чи здоров'я потерпілого або погрози його застосування).

У науці кримінального права існують суперечності щодо місця насильства під час нападу та їх співвідношення. Доказом цього $є$ факт існування як прихильників які визнають тавтологією напад та насильство у формулюванні наведеному у ст. 187 КК України, так і прихильників визнання нападу самостійною ознакою. П. С. Матишевський зазначає, що хоча закон визначає розбій за допомогою вказівки на два роди дій, що обираються винним, - напад і насильство - сутність їх одна, оскільки це двоєдиний спосіб заволодінням майном, а тому навряд чи можна встановити, як це намагаються зробити окремі автори, чіткі юридичні критерії, що дозволяють розмежувати напад і насильство [11, с. 95]. А. Д. Гаухман виокремлює напад як обов'язкову ознаку об'єктивної сторони складу злочину розбою, а вказане насильство та погрозу - альтернативними ознаками. Тобто, об'єктивна сторона складу розбою наявна при поєднані нападу та насильства, небезпечного для життя чи здоров'я, або нападу і погрози застосування такого насильства [12, с. 208]. Визначаючи поняття нападу В. К. Грищук зазначає, що це є спосіб вчинення злочину, який становить собою несподіване, раптове, умисне, кримінально-протиправне, насильницьке посягання на об'єкт (об'єкти) кримінально правової охорони. [13, ст. 39-40].

Обов'язковою ознакою розбою є корисливий мотив нападу. Напад, учинений не 3 корисливих спонукань (за мотивом помсти, ревнощів чи хуліганських спонукань), не може кваліфікуватися як розбій [14, с. 94].
Таким чином, під нападом у складі розбою слід розуміти раптову, несподівану для потерпілого, короткочасну, агресивну, насильницьку дію, спрямовану на протиправне заволодіння чужим майном. Напад може бути як відкритим, так і таємним (наприклад, нанесення удару потерпілому з-за спини). Напад обов'язково повинен виявлятися у психічному або фізичному насильстві, яке має реальний характер: воно здатне пригнітити волю потерпілого і примусити його передати майно винному. За цією ознакою розбій відрізняється, з одного боку, від крадіжки, з іншого, - від грабежу.

Напад органічно пов'язаний із фізичним або психічним насильством, яке при розбої має так званий інструментальний характер виступає способом заволодіння майном або його утримання. При цьому фізичне насильство може полягати у протиправному впливі не лише на зовнішні частини тіла потерпілого (механічне їх травмування), а й внутрішні (отруєння), а також в інших діях насильницького характеру, які створюють небезпеку для життя чи здоров'я потерпілого (скажімо, насильницьке тримання його в небезпечних для життя та здоров'я умовах). У разі, якщо застосування чи погроза застосування насильства, небезпечного для життя чи здоров'я особи, здійснювались 3 метою ухилитись від затримання після закінченого нападу, вчинене не може розглядатися як розбій.

Під насильством, небезпечним для життя чи здоров'я особи, яка зазнала нападу, слід розуміти заподіяння їй легкого тілесного ушкодження, що спричинило короткочасний розлад здоров'я або незначну втрату працездатності, середньої тяжкості або тяжкого тілесного ушкодження (останнє кваліфікується за ч. 4 ст. 187 КК), а також інші насильницькі дії, які не призвели до вказаних наслідків, але були небезпечними для життя чи здоров'я в момент заподіяння (насильство, що призвело до втрати свідомості чи мало характер мордування, здушення шиї, скидання з висоти, застосування електроструму, зброї, спеціальних знарядь тощо). Погроза застосувати небезпечне фізичне насильство повинна бути безпосередньою і очевидною, тобто у потерпілої особи має скластись враження - якщо вона буде протидіяти нападаючому або не вико- 


\section{Дискусії, обговорення, актуально}

нає його вимог, ця погроза буде негайно реалізована. Вважається, що лише така погроза здатна придушити, зламати волю потерпілого, примусити його виконати майнові вимоги злочинця. Головним критерієм реальності погрози, як це випливає з роз'яснення, що міститься у Постанові Пленуму Верховного Суду України «Про судову практику у справах про злочини проти власності» від 6 листопада 2009 р. № 10, є суб’єктивне сприйняття потерпілого. Для кваліфікації дій за ст. 187 КК важливо, щоб у потерпілої особи в конкретній ситуації склалося враження, що у разі протидії чи невиконання вимоги погроза буде здійснена і небезпечне фізичне насильство до неї застосоване. При цьому особа, яка вчинює розбійний напад, з різних причин може планувати фактичне незастосування фізичного насильства (не здатна подолати певні психологічні бар'єри, вирішила обмежитись лише залякуванням потерпілого тощо).

Суб'єктом розбою є осудна особа, яка досягла 14-річного віку. У 5,7\% (у 14 із 242 досліджених кримінальних проваджень) суб'єктом виступала особа яка не досягла 18 років, тобто неповнолітній.

Суб'єктивна сторона злочину характеризується прямим умислом та корисливим мотивом. Обов'язковою ознакою суб'єктивної сторони розбою є мета, з якою здійснюється напад, - заволодіння чужим майном [15; 16].

Кримінологічний аналіз розбійних нападів на житло громадян вказує на особливості способів та інші ознаки їх вчинення, що дає підстави віднесення їх до особливих об'єктів кримінологічної безпеки, які потребують досягнення певного ступеня захищеності, а відтак здійснення комплексу організаційних і спеціальних заходів, спрямованих на забезпечення безпеки людей, власності від злочинних посягань.

Для більш зручного розгляду способу вчинення розбійних нападів на житло громадян, можна виокремити три етапи, а саме:

1) приготування до вчинення розбійного нападу на житло, яке може полягати у наступному: в підборі співучасників та розподіленні ролей; в придбані, переробці та виготовленні зброї, різноманітних знарядь зламу, а також засобів пересування; збір інформації про об'єкт нападу (наявність охоронних систем, перебування громадян вдома тощо); в маскуванні зовнішності злочинців, транспортного засобу; необхідності знищення слідів злочину в цілому; підготовка місць для подальшого зберігання награбованого, та знарядь злочину; 2) безпосереднє вчинення розбійного нападу на житло громадян; 3) приховування слідів розбійного нападу на житло громадян. 3 метою приховати сліди нападу, а також унеможливити використання розшукових засобів та службо-розшукової собаки, злочинці здебільшого застосовують: рукавички, умисну зміну голосу та мови, витирання ганчіркою предметів, спалювання предметів 3 якими мали фізичний контакт та до яких торкались, використання речовин, які нейтралізують запах (тютюн, бензин, одеколон).

Таким чином, запобігання розбійним нападам на житло громадян 6 необхідною умовою становлення правової держави, яке здійснюється на загальносоціальному та спеціальному рівнях. Спеціальне запобігання здійснюеться на основі загальносоціального запобігання шляхом правового реагування на вчинення злочинів та спеціально-кримінологічного запобігання новим злочинам. Запобігання злочинності є сформованою системою дій стосовно антисуспільних явищ та їх причинного комплексу 3 метою розширення тенденції зниження рівня і масштабів злочинності та їі викорінення.

Підводячи підсумки, необхідно зазначити, що характерними ознаками розбійних нападів на житло громадян, як об'єкту кримінологічного дослідження є сукупність спеціалізованої наукової інформації, що включає в себе такі елементи: соціальну обумовленість встановлення та збереження кримінальної відповідальності за певний вид злочинів; суспільну небезпечність певного виду злочинів; протиправність діяння та іï місце у системі нормативного визначення заборони відповідного виду суспільно-небезпечної поведінки; склад певного виду злочинів; суспільно небезпечні наслідки та інші обставини вчинення злочинів, що перебувають поза межами складу певного виду злочинів, але притаманні їх вчиненню; заходи запобігання.

Даний вид розбою поєднує в собі корисливий мотив та насильницькі дії (як фізичного так і психічного характеру) або погрозу їх 
застосування й посягають на життя і здоров’я людини.

Системоутворюючою властивістю, що поєднує корисливий мотив і насильницьке його досягнення, виступає інваріантна кримінальна діяльність особи злочинця у своєму розвитку [17, с. 49], де корисливий мотив визначає характер, зміст і природу, а насильницька форма його реалізації конкретизує спрямованість цієї специфічної злочинної діяльності. Таким чином, розбійні напади на житло громадян можна визначити як антисочіальне явище й відносно масове суспільно-небезпечне збагачення, що проявляється у вииненні розбійних нападів на примішення, призначене для постійного або тимчасового проживання людей (будинок, квартира, дача тощо), характеризується як правило груповим характером та розподілом ролей, поєднаних $i_{3}$ застосуванням чи погрозою застосування насильства .

\section{Лiтература}

1. Про зареєстровані кримінальні правопорушення та результати їх досудового розслідування. Генеральна прокуратура Украӥни. URL: http://www.gp.gov.ua/ua/stat.html.

2. Довідка про злочини, учинені в Україні за 2014-2019 рр.: службовий документ. Департамент аналітичної роботи та організації управління МВС України. Київ, 2020. 124 c.

3. БатиргареєваВ.С.Кримінологічна характеристика та попередження розбоїв, поєднаних з проникненням у житло. Харків : Одиссей, 2003. 256 с.

4. Кримінальне право України: Особлива частина: підручник / М. І. Бажанов, Ю. В. Баулін, В. І. Борисов та ін.; за ред. М. I. Бажанова, В. В. Сташиса, В. Я. Тація. 2-ге вид., перероб. і допов. Київ: Юрінком Інтер, 2005. 544 c.

5. Кримінальне право України. Загальна частина : підручник / Бажанов М. I., Баулін Ю. В., Борисов В. І. та ін.; за ред. проф. М. I. Бажанова, В. В. Сташиса, В. Я. Тація. 2-ге вид., перероб. і доп. Київ : Юрінком Інтер, 2004. 480 c.

6. Волков Б. С. Проблема воли и уголовная ответственность. Казань : Изд-во Казан. ун-та, 1965. 136 с.
7. Уголовное право Украины. Общая часть : учебник / Бажанов М. И., Баулин Ю. В., Борисов В. И. и др.; под ред. М. И. Бажанова, В. В. Сташиса, В. Я. Тация. Киев : Юринком Интер, 2003. 512 с.

8. Панов Н. И. Способ совершения преступления и уголовная ответственность. Харьков : Вища школа, 1982. 160 с.

9. Ярмыш Н. Н. Действие как признак объективной стороны преступления (проблемыпсихологической характеристики). Харьков : Основа, 1999. 84 с.

10. Про судову практику у справах про злочини проти приватної власності: постанова Пленуму Верховного Суду України від 6 листоп. 2009 р. № 10. Верховна Рада украӥни. URL: http://zakon2.rada.gov.ua/laws/ show/v0010700-09

11. Матышевский П.С.Преступления против собственности и смежные с ними преступления: монография. Киев: Юринком, 1996. 240c.

12. Гаухман $\lambda$. Д. Квалификация преступлений: закон, теория, практика: пособие. М.: АО «Центр ЮрИнфоР», 2011. 316 с.

13. Грищук В. К. Напад у кримінальному праві. Юридична енщиклопедія: в 6 т. / редкол.: Ю. С. Шемшученко (відп. ред.) та ін. Київ: «Укр. енцикл.», 1998. Т. 4: Н-П., 2002. 768 c.

14. Селецький C. I. Кримінальне право України. Особлива частина: навч. посіб. Київ: Центр учбової літератури, 2008. 496 с.

15. Науково-практичний коментар Кримінального кодексу України / Д. С. Азаров, В. К. Грищук, А. В. Савченко [та ін.]; за заг. ред. О. М. Джужі, А. В. Савченка, В. В. Чернєя. Київ: Юрін-ком Інтер, 2016. 1064 с.

16. Кримінальний кодекс України. Науково-практичний коментар : у 2 т. / за заг. ред. В.Я. Тація, В.П. Пшонки, В.І. Борисова, B.I. Тютюгіна. - 5-те вид., допов. - Т. 2 : Особлива частина / Ю.В. Баулін, В.І. Борисов, B.I. Тютюгін та ін. Харків: Право, 2013. 1040 с

17. Головкін Б. М. Теоретичні та прикладні проблеми детермінації і запобігання корисливій насильницькій злочинності в Україні: дис. ... докт. юрид. наук: 12.00.08. Харків, 2011. 406 с. 


\section{Дискусіі, обговорення, актуально}

Розбійні напади на житмо громадян як об'єкт кримінологічного дослідження

У статті надана характеристика розбійним нападам на житло громадян 3 позиції кримінологічного підходу. Розкрито елементи кримінологічної характеристики, ознаки та поняття розбійних нападів на житло громадян. До елементів кримінологічної характеристики віднесено: об'єкти (житло громадян, розбійний напад як діяльність), суб'єкти та заходи запобігання. характерними ознаками розбійних нападів на житло громадян, як об’єкту кримінологічного дослідження є сукупність спеціалізованої наукової інформації, що включає в себе такі елементи: 1) соціальну обумовленість встановлення та збереження кримінальної відповідальності за певний вид злочинів; 2) суспільну небезпечність певного виду злочинів; 3) протиправність діяння та іiі місце у системі нормативного визначення заборони відповідного виду суспільно-небезпечної поведінки; 4) склад певного виду злочинів; 5) суспільно небезпечні наслідки та інші обставини вчинення злочинів, що перебувають поза межами складу певного виду злочинів, але притаманні їх вчиненню; 6) заходи запобігання.

Даний вид розбою поєднує в собі корисливий мотив та насильницькі дії (як фізичного так і психічного характеру) або погрозу їх застосування й посягають на життя і здоров'я людини.

Системоутворюючою властивістю, що поєднує корисливий мотив і насильницьке його досягнення, виступає інваріантна кримінальна діяльність особи злочинця у своєму розвитку, де корисливий мотив визначає характер, зміст і природу, а насильницька форма його реалізації конкретизує спрямованість цієї специфічної злочинної діяльності. Таким чином, розбійні напади на житло громадян можна визначити як антисоціальне явище й відносно масове суспільно-небезпечне збагачення, що проявляється у вчиненні розбійних нападів на приміщення, призначене для постійного або тимчасового проживання людей (будинок, квартира, дача тощо), характеризується як правило груповим характером та розподілом ролей, поєднаних із застосуванням чи погрозою застосування насильства.
Ключові слова: розбій, власність, житло, кримінологічна характеристика, запобігання.

\section{Robbery on the housing of citizens as a sub- ject of criminological research}

The article characterizes robbery attacks on the housing of citizens from the standpoint of criminological approach. The elements of criminological characteristics, signs and concepts of robbery on housing of citizens are revealed. The elements of criminological characteristics include: objects (housing, robbery as an activity), subjects and measures of prevention. characteristic features of robbery attacks on housing of citizens, as the object of criminological research is a set of specialized scientific information, which includes the following elements: 1) social conditionality of establishing and maintaining criminal liability for a certain type of crime; 2) social danger of a certain type of crime; 3) the unlawfulness of the act and its place in the system of normative determination of the prohibition of the corresponding type of socially dangerous behavior; 4) composition of certain types of crimes; 5) socially dangerous consequences and other circumstances of committing crimes that are outside the composition of a certain type of crime, but are inherent in their commission; 6) prevention measures.

This type of robbery combines selfish motive and violent actions (both physical and mental in nature) or the threat of using them and affecting the life and health of a person.

The system-forming property that combines selfish motive with its violent achievement is the invariant criminal activity of the offender in its development, where the selfish motive determines the character, content and nature, and the violent form of its realization specifies the orientation of this specific criminal activity. Thus, robberies on housing of citizens can be defined as an antisocial phenomenon and relatively mass socially dangerous enrichment, which is manifested in committing robberies on premises intended for permanent or temporary residence of people (house, apartment, cottage, etc.), characterized as a rule by group. the nature and distribution of roles associated with the use or threat of violence.

Keywords: robbery, property, housing, criminological characteristics, prevention $\phi$ 